\title{
Challenges That Academic Library Directors Are Experiencing as Perceived by Them and Their Supervisors
}

\section{Eileen McElrath}

The study examines perceptions of challenges reported by academic library directors and the chief academic officers to whom they report. Findings indicate that perceptions about user satisfaction were similar, that the challenge of serials was perceived to be the greatest challenge, that perceptions are related about the challenges of diversity and hardware, and that challenges of organizational change and crime in libraries appear to be influenced by age and length of tenure. Findings further indicate that training and the budget are related.

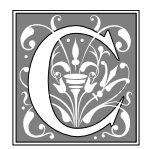

hallenges that current academic library directors (ALDs) are experiencing as perceived by the directors and the chief academic officers (CAOs) to whom they report are the focus of this research. Much is known about the challenges of library directors who belong to the Association of Research Libraries (ARL). Less is known about the library directors in public academic institutions. The present study gathered information from current ALDs and CAOs in public academic universities in the South with Carnegie Classification Master I and Master II, a rarely studied group.

The field's literature documents the ubiquitous change that is taking place in academic libraries as well. Change brings with it new challenges for an organization. Academic libraries are especially affected by these changes. "While the his- tory of change in higher education has been one of slow incremental steps, college and university libraries have undergone dramatic changes over the past twenty years," stated Charles G. Newman in "Selection, Career Paths, and Managerial Development in Academic Library Administration: Forecasting the Needs of the Twenty-first Century. ${ }^{1}$

The library director serves as "the principal moderator between the internal organization and portions of the external environment that controls the domain and resource flow to the organization," wrote Joanne R. Euster. ${ }^{2}$ A key relationship exists between the library director and the director's supervisor who works in the "external environment that controls the domain and resource flow to the organization." ${ }^{3}$ The director's supervisor (the CAO) may rarely see the ALD or even come into the changing library, yet the

Eileen McElrath is Assistant Professor of Library and Information Science at Valdosta State University; e-mail: rebleemc@aol.com. 
individuals are interrelated administrators in the university.

Some CAOs think the budget is the way to help the ALD, according to Larry Hardesty, and that is the extent of their support. ${ }^{4}$ Favorable budgetary decisions certainly are vital for the academic library to survive. If there are differences in the perceptions of challenges encountered by library directors, it is logical to assume a resultant discrepancy in the support given by the CAO. Negotiations may be affected to the disadvantage of the library. Because full-time employee (FTE) staffing numbers are directly tied to budget, it is reasonable to assume that FTEs are affected as well.

\section{Although some studies have con- cluded that it is the poorer workers who leave, there is evidence to suggest that persons who leave may be the better performers. ${ }^{7}$}

A frequently cited study by Arthur M. McAnally and Robert B. Downs is credited with important documentation of problems identified by Association of Research Libraries (ARL) directors. In addition, McAnally and Downs documented a trend toward shortened tenures of ALDs. ${ }^{5}$ Other studies have confirmed that many ALDs are continuing to leave the position. ${ }^{6}$ There are multiple reasons why an ALD may leave his or her position. One explanation is that the turnover may be normal because directorships may have been acquired late in careers. Another explanation may be a lack of understanding by their supervisors about the challenges that the ALD is experiencing in times of rapid change.

Leadership change can have a positive impact by bringing fresh ideas into the organization. Leadership turnover studies have established that leadership change, on the other hand, can also be disruptive because the uncertainty it creates can lower group performance and morale. Although some studies have concluded that it is the poorer workers who leave, there is evidence to suggest that persons who leave may be the better performers. $^{7}$

A clearer understanding of different perspectives of these challenges may lead to the use of techniques to keep good ALDs from leaving. It is expensive to hire new directors; and it is important to realize that there is no guarantee that the new director will stay. When the costs of turnover and the potential negative result to the library are considered, it is important to learn reasons for the increased turnover in the ALD position. The ALD may be unable to do what the administration wants and may just leave or be encouraged to leave. Identification of the challenges can help a search committee focus on needed skills or characteristics in the next ALD as well.

\section{Purpose of the Study}

The primary purpose of this study was to identify current ALD challenges and to compare ALDs' perceptions of challenges with those held by the CAOs to whom they report. A second purpose was to determine whether differences in perspectives between the two groups have a relationship with budget, staffing, or the number of times the two groups meet. Variables such as age, gender, and length of time in current position were included to determine whether these variables were influencing perceptions. Length of tenure in present position, and the number and type of academic degrees held along with age and gender information, provided current information for this comparison. Finally, this study attempts to fill the research void currently existing about ALDs in public institutions with Carnegie Classification Master I and Master II and their challenges. Other studies have examined large libraries and/or libraries belonging to the ARL. Few studies have been conducted to learn about challenges being experienced by ALDs working in smaller public universities.

\section{Review of the Literature}

Authors in the library/information studies field have documented the importance 
of ALDs and the turnover in directors. In 1993, McAnally and Downs interviewed ARL directors who had resigned or transferred from directorships to provide a basic description of problems besetting the directors. Identified problems included growth of enrollment, added layers of hierarchy between librarians and administrators with power, growth of information, reduced budgets, shifts from autocratic to participative or political management approaches, unionization of library staffs, increase in the power of state boards of higher education, and no backup network to improve access to information. ${ }^{8}$ As mentioned earlier, McAnally and Downs documented a trend toward shortened tenures of ALDs, with other studies confirming the trend. ${ }^{9}$

" The two most difficult and challenging positions on any research campus are those of chancellor and director of libraries" and "These are the two positions with the largest number of constituencies possessing significant and divergent expectations," related Ruth J. Person and Sharon J. Rogers of an observation given by a University of Wisconsin-Madison chancellor. ${ }^{10}$ Person and Rogers also stressed in Recruiting the Academic Library Director that the academic library director manages a "high-priced operation that is vital to both instruction and research" and, at the same time, must compete with other campus units for the "institution's fiscal resources." 11

The rate of change in library and information technologies is stressing the need for diverse skills. In her 1997 article, "The Library, Information, Institutional Outcomes: Searching in a Time of Change," Barbara Brittingham, dean of the College of Human Sciences and Services at the University of Rhode Island, observed that "the work, context, and possibilities are changing so quickly that candidates [for the director's position] with sufficient administrative seasoning for senior positions must have developed interests, knowledge, and skills that go far beyond what the leaders in their fields had 20 years ago."12 This skilled informa- tion professional manager is highly desirable in large part because of the tremendous effect the ALD has on the library staff and the future of the library according to Paul J. Kobulnicky. Kobulnicky also stressed that the rate of change (in 1997) currently being experienced by libraries has increased the importance of effective leadership in the library when he wrote:

The staff must be able to rely on leadership, especially the director, to help them manage change. The library director must build, with the staff, an effective vision for the future and then guide the library toward that vision. If the director's position itself lacks stability, then there is a great potential for the entire staff to respond negatively and for the organization's services to suffer. ${ }^{13}$

Donald E. Riggs and Gordon A. Sabine's 1988 study of twenty-five library leaders (academic library directors were included, but not exclusively) provided insight into their self-identified leadership characteristics, how they would suggest a newcomer become a leader, and what leadership attributes they predict would be needed in 1998. Additional issues examined by Riggs and Sabine include characteristics of library users in 1998, effects of automation, getting a budget approved, and continuing education. ${ }^{14}$

Other eras also have experienced tremendous changes as Susan Jurow, director of ARL's Office of Management Services, pointed out in "Preparing Academic and Research Library Staff for the 1990's and Beyond." Jurow explained that the difference is that "along with the complex and large-scale character of the changes facing us, the rapid rate and ongoing nature of these change processes leaves us with a sense of constantly being in a state of flux or transition." She reported that in 1990, "Almost $25 \%$ of the ARL member libraries have changed directors in the last four years." ${ }^{15}$ Jurow did not speculate on the numerous reasons the library directors may have had for 
changing jobs. However, one implication is that the concerns and challenges that come with such rapid change may be contributors.

Rapid change may be a factor, but only one of several. Moreover, the turnover continues. Kolulnicky reported that, as of January 1996, twenty-four of the 119 members of the ARL were somewhere in the process of changing leadership. ${ }^{16}$ Economic costs are involved with replacing any employee as well. When it comes to hiring a new ALD, Barbara Brittingham stressed: "Hiring the wrong person can easily cost an institution a quarter of a million dollars before the mistake is rectified; hiring a marginally successful person can cost much more."17

A number of attempts have been made to examine and promote the relationship between ALDs and the CAOs to whom they report. ${ }^{18}$ The relationship has been characterized as one of low priority on the part of the CAOs. ${ }^{19}$ Further, research has suggested that the CAOs' decisions affect academic library budgets. Research also has suggested that ALDs have some impact on budget decisions. ${ }^{20} \mathrm{~A}$ significant negative relationship in differences in perceptions between the two respondent groups and the budget and/or FTE staffing numbers would indicate that the outcomes are being affected negatively.

It is important to understand the challenges that the director experiences because, as Thomas W. Shaughnessy asserted, "it will be today's academic library leaders who make the transformational changes needed for the libraries of the future." ${ }^{21} \mathrm{New}$ insights are needed for understanding the ALD's challenges in the current academic library environment.

\section{Methodology}

This study used content analysis of journal articles, a panel of experts, and a crosssectional survey consisting of self-administered questionnaires for data collection in late 1999. The topics for the questions are based on the researcher's content analysis of article topics appearing in three professional journals in the past five years: College E Research Libraries, Journal of Academic Librarianship, and Library Administration $\mathcal{E}$ Management. Two assumptions were made: (1) The frequency of the topics indicates challenges, and (2) the challenges are not all the challenges or the most important challenges that ALDs experience. A panel of experts from the field was used to validate the challenges.

\section{CAOs with the shorter length of tenure in their present positions may have come to their positions with preconceived ideas about what challenges the ALDs are encounter- ing.}

The survey's potential participants were ALDs and the CAOs to whom they report who are working in state-funded universities that are classified as Carnegie Masters I or II institutions and are located in the American Association of Public Colleges and Universities' (AAPCU) southern region (Alabama, Arkansas, Florida, Georgia, Louisiana, Mississippi, North Carolina, Oklahoma, South Carolina, Tennessee, and Texas). Masters I and II institutions offer bachelor and master's degrees only. Eighty-six institutions were identified that possessed these qualifications. Temporary or acting administrators were eliminated because it was assumed that they might perceive different challenges because of their status. This reduced to seventy-two the possible survey participants in one group whose responses could be matched with a corresponding seventytwo in the other group, although 161 potential respondents comprised the total sample of ALDs and the CAOs in the study. The survey had an overall usable response rate $(156 / 118)$ of 75.6 percent. The total matched institutions response rate (72/44) was 61.1 percent.

A cross-sectional survey provides a "snapshot" (a one-time look) at a group of people or an organization. The researcher developed survey instruments to collect the data. A pilot study was conducted and the questions revised accordingly. The first section of each question- 
naire collected demographic information including age, gender, length of tenure in current position, and academic degrees held. The second section contained questions about specific challenges identified in the literature. Participants were asked to respond using a Likert-type scale (15). The last section asked respondents to list, in order of importance, up to three additional challenges that ALDs may be experiencing. They next were asked to rank up to three out of the total list of challenges (provided and added) in order or importance. The ALDs provided budget and staffing information.

Descriptive and statistical analyses of the data allowed inferences to be made about the usefulness of perceptions and differences of those perceptions of current challenges. Data were analyzed using frequencies, measures of central location, and variance. Pearson Product Moment Correlations and Point Biserial Correlations were used to determine relationships, where appropriate. The responses for the present research were examined at the $\mathrm{p}<.05$ level of significance. Each correlation represents a relationship as well as the strength of a linear relationship. A positive correlation, if found, would indicate that as the response scores of one group go up, the response scores of the other group go up and as the response scores of one group go down, so do the response scores from the other group. Conversely, a negative correlation, if found, would indicate that as the response scores of one group go up, the response scores of the other group go down, and vice versa. An independent twotailed t-test was conducted for responses to each of the eight survey-provided challenges to determine whether a significant difference in the means of the two groups' responses exists.

\section{Contribution of the Study}

The study contributes to the field by providing information about challenges affecting key administrators. ALDs' views after they have had experience in the position are valuable not only to them, but to others as well. New techniques to increase communication and understanding between ALDs and the CAOs to whom they report may be indicated. The

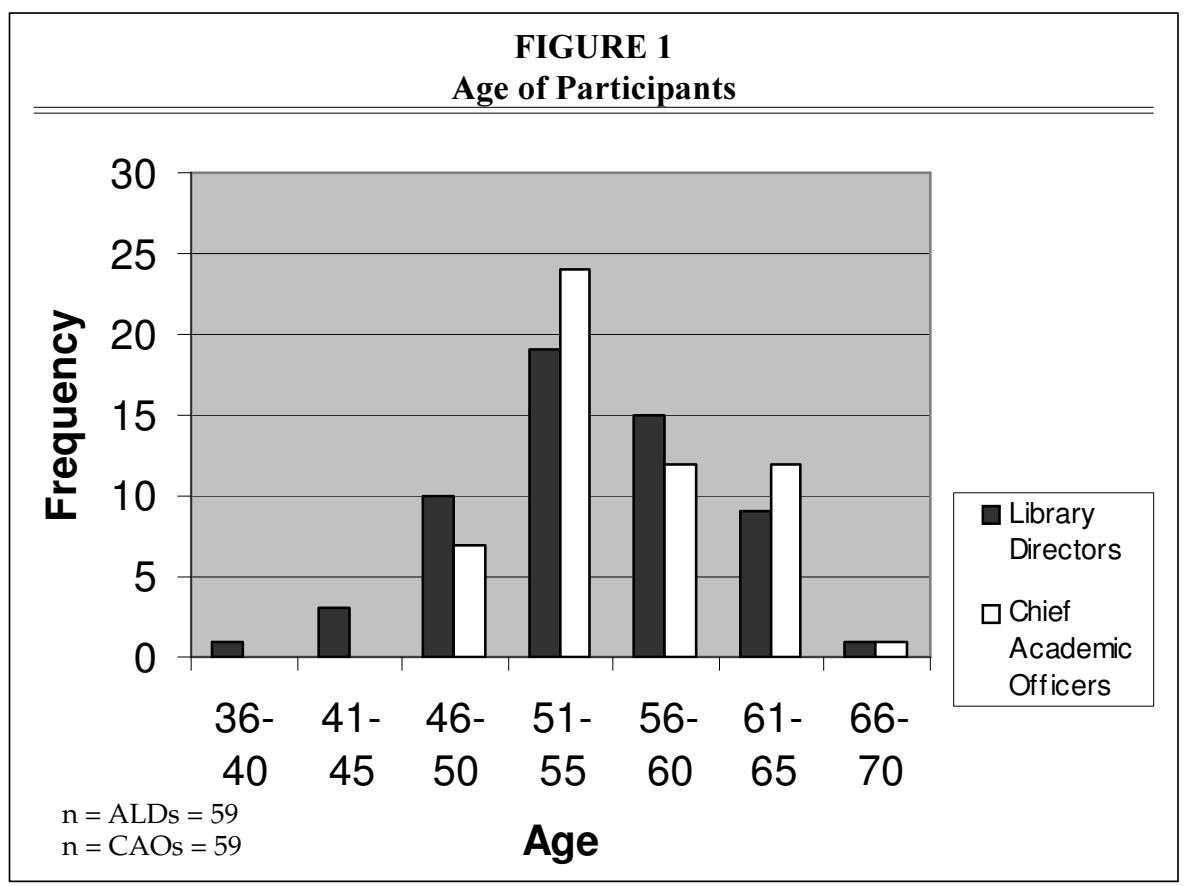




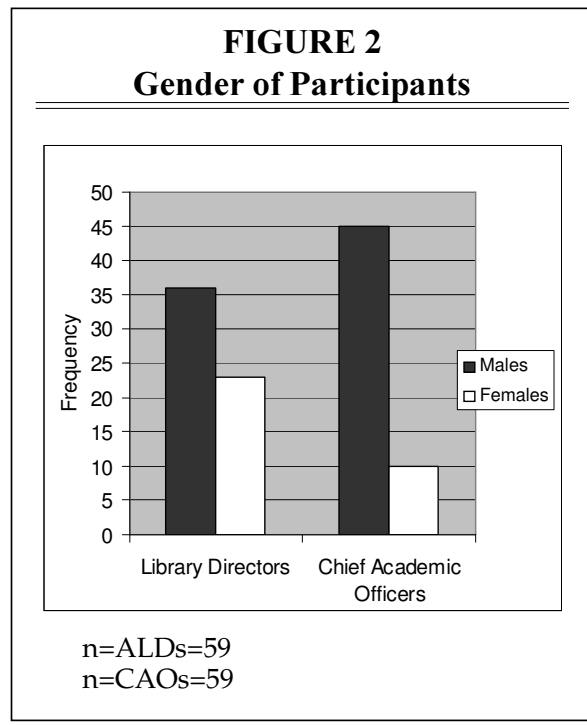

result of the increased understanding may benefit the library users, faculty, and staff.

CAOs can be better informed when providing resources to the library and when evaluating the ALD. The study provides insights that will help to determine the skills needed when recruiting a new ALD. In addition, assuming that Newman's statement about the college and university libraries changing much more rapidly than the rest of the university is correct, the study alerts the CAO to challenges that the rest of the university may be encountering shortly.

New ALDs will be aware of the need to acquire appropriate management and political skills to address the challenges identified. The study also provides information that Schools of Information Studies and / or Library and Information Studies might use to add to the evaluation of their management courses. In addition, the challenges identified may be experienced by managers from other fields and may stem from challenges with administrative support systems. Finally, this study will help fill a gap in the literature of the profession about a rarely studied group, ALDs and academic libraries in public institutions with Carnegie Classification Master I and Master II.

\section{The Study Respondents}

The frequencies given for age, gender, time in position and discipline of degrees describe the participants.

Age

The average age reported by the ALDs is fifty-seven. The average age reported by the CAOs is fifty-eight. Figure 1 provides this information.

\section{Gender of All Participants}

Figure 2 presents the reported gender from the survey respondents. Males dominate the library director group with thirty-six (61.0) compared with twentythree $(39.0 \%)$ females. The gender gap is more pronounced for the group of CAOs with forty-five males $(81.8 \%)$ and only ten females $(18.2 \%)$.

\section{Length of Time in Position}

The average length of time in their present position for the ALDs is 10.54 years. The CAOs report an average of 6.61 years. More than half of the CAOs (59.3\%) have been in their positions five years or less whereas only 35.6 percent of the ALDs have been in their positions five years or less.

One implication for any difference in perspectives about challenges is that CAOs with the shorter length of tenure in their present positions may have come

\begin{tabular}{|l|rr|rr|}
\hline \multicolumn{5}{|c|}{ TABLE 1 } \\
\multicolumn{4}{|c|}{ Length of Time in Position } \\
\hline \hline & \multicolumn{2}{|c|}{ ALD } & \multicolumn{2}{c|}{ CAO } \\
\hline Years & Freq & \multicolumn{1}{c|}{ \% } & Freq & \% \\
\hline $1-5$ & 21 & 35.6 & 35 & 59.3 \\
$6-10$ & 13 & 22.0 & 10 & 16.9 \\
$11-15$ & 9 & 15.2 & 7 & 11.9 \\
$16-20$ & 4 & 6.8 & 2 & 3.4 \\
$21-25$ & 2 & 3.4 & 3 & 5.1 \\
$26-32$ & 7 & 11.9 & 0 & 0.0 \\
No answer & 3 & 5.1 & 2 & 3.4 \\
Total & 59 & 100.0 & 59 & 100.0 \\
\hline $\mathrm{n}_{1}=\mathrm{ALD}=59$ & \multicolumn{5}{|}{} \\
$\mathrm{n}_{2}=\mathrm{CAO}=59$ &
\end{tabular}




\begin{tabular}{|c|c|c|}
\hline \multicolumn{3}{|c|}{$\begin{array}{c}\text { TABLE } 2 \\
\text { Disciplines of Degrees Held by } \\
\text { Academic Library Directors } \\
\end{array}$} \\
\hline Master's Degree & Frequency & $\%$ \\
\hline LIS & 57 & 96.5 \\
\hline Education & 2 & 2.7 \\
\hline English & 4 & 5.3 \\
\hline History & 10 & 13.3 \\
\hline Science & 0 & .0 \\
\hline Other: & 14 & 18.6 \\
\hline Business & 2 & 2.7 \\
\hline Agricultural Economics & 1 & 1.3 \\
\hline Spanish & 1 & 1.3 \\
\hline Communication & 1 & 1.3 \\
\hline German Literature & 1 & 1.3 \\
\hline MBA & 2 & 2.7 \\
\hline Theology & 1 & 1.3 \\
\hline Political Science & 1 & 1.3 \\
\hline MST (Taxation) & 1 & 1.3 \\
\hline Speech and Drama & 1 & 1.3 \\
\hline French Literature & 1 & 1.3 \\
\hline Rhetoric and Writing & 1 & 1.3 \\
\hline Doctorate Degree & Frequency & $\%$ \\
\hline LIS & 11 & 14.7 \\
\hline Education & 9 & 12.0 \\
\hline English & 1 & 1.3 \\
\hline History & 3 & 4.0 \\
\hline Science & 0 & .0 \\
\hline Other & 3 & 4.0 \\
\hline Romance Languages & 1 & 1.3 \\
\hline German Linguistics & 1 & 1.3 \\
\hline Management & 1 & 1.3 \\
\hline \multicolumn{3}{|l|}{ Other Degrees } \\
\hline Specialist in LIS & 1 & 1.3 \\
\hline Diploma in Adv. Studies & 1 & 1.3 \\
\hline $\mathrm{n}=59$ & & \\
\hline
\end{tabular}

most frequently reported discipline for a doctorate degree is in library and information science $(14.7 \%)$. One CAO (1.8\%) reported holding a doctorate degree in library and information science (LIS). The most frequently reported doctorate degree held by CAOs is in the humanities $(25.4 \%)$. Twenty-seven $(45.8 \%)$ of the ALDs report holding doctorate degrees. Sixty-one $(72.7 \%)$ hold multiple degrees. The CAOs hold forty-one master's degrees and one doctorate. Only two CAOs hold no advanced degrees.

Both the ALDs and the CAOs are members of well-educated groups. The multiple degrees held by many of the participants may be explained by the nature of the institutions within which they work. It is reasonable to assume that academic institutions attract people who value education for themselves as well as for others. Another explanation for the multiple degrees held by the ALDs is the necessity of acquiring the second degree as a minimum requirement for tenure in many institutions. A second degree in a subject discipline is helpful in a library career as well. Due to multiple degrees, the percentages do not total 100 percent.

\section{Findings and Discussion: The Research Questions}

To what degree do perspectives of challenges given by current ALDs coincide with the perceptions of the CAOs to whom they report? Perspectives of to their positions with preconceived ideas about what challenges the ALDs are encountering.

\section{Disciplines of Degrees}

As shown in table 2, the most frequently reported discipline for the ALDs is a master's degree in library and information science (fifty-seven, or $96.6 \%$ ). For the CAOs (table 3), the most frequently reported discipline for a master's degree is in social sciences (22.0\%). The ALDs' challenges between the ALDs and the CAOs show the same mean for user satisfaction indicating similarity of perceptions about this challenge. In addition, perspectives related on the challenges of diversity and hardware. As one group rated these challenges as more intense, so too did the other group. As one group rated these challenges as less intense, so too did the other group. A possible explanation for this finding is that both diversity and hardware are campuswide issues, so the two groups 


\begin{tabular}{|c|c|c|}
\hline \multicolumn{3}{|c|}{$\begin{array}{c}\text { TABLE } 3 \\
\begin{array}{c}\text { Disciplines of Degrees Held by Chief } \\
\text { Academic Officers }\end{array} \\
\end{array}$} \\
\hline Master's Degree & Frequency & $\%$ \\
\hline Humanities & 10 & 13.3 \\
\hline Social Sciences & 13 & 22.0 \\
\hline Education & 8 & 13.5 \\
\hline Science & 9 & 15.3 \\
\hline Mathematics & 5 & 8.5 \\
\hline Other: & 8 & 13.5 \\
\hline Music & 1 & 1.3 \\
\hline Library Science & 1 & 1.3 \\
\hline Business & 2 & 2.7 \\
\hline MBA & 2 & 2.7 \\
\hline Engineering & 1 & 1.3 \\
\hline \multicolumn{3}{|l|}{ Family \& } \\
\hline Consumer Sci. & 1 & 1.3 \\
\hline Doctorate Degree & Frequency & $\%$ \\
\hline Humanities & 15 & 25.4 \\
\hline Social Sciences & 13 & 22.0 \\
\hline Education & 12 & 20.3 \\
\hline Science & 11 & 18.6 \\
\hline Mathematics & 3 & 5.1 \\
\hline Other: & 5 & 8.4 \\
\hline Business & 1 & 1.3 \\
\hline Business Management & 1 & 1.3 \\
\hline Management & 1 & 1.3 \\
\hline Engineering & 1 & 1.3 \\
\hline Library Science & 1 & 1.3 \\
\hline \multicolumn{3}{|l|}{ Other Degrees } \\
\hline BA in Political Science & 1 & 1.3 \\
\hline $\mathrm{BS}$ & 1 & 1.3 \\
\hline Ed.D & 3 & 5.1 \\
\hline DMA in Percussion Perf. & 1 & 1.3 \\
\hline MRE & 1 & 1.3 \\
\hline $\mathrm{n}=59$ & & \\
\hline
\end{tabular}

to the ARL and the Association of College and Research Libraries (ACRL) was a common vision of the future where universal access to information is provided by multifunctional workstations. ${ }^{22}$ To accomplish that goal, hardware and software would have to be purchased. The present study's findings indicate that the goal of the study's public institutions is similar to the ARL and the ACRL member libraries.

Organizational diversity goals cross department lines, as well. Diversity is a societal concern; thus, diversity in student body and in employee needs is a campus issue with which these administrators would be aware. A t-test of difference of means did not show a significant difference in the means for the two groups on any of the challenges (table 4).

To what degree are differences in perspectives between the two groups reflected in library budgets and staffing numbers? The study used the organizational outcomes of budget and staffing numbers to determine whether differences in perspectives about challenges held by the respondent group related to budget and/ or FTE staffing numbers. The study acknowledges that many factors influence budget decisions and staffing decisions. Legislative action, for example, influences budgets tremendously in publicly supported institutions. Tax income shortfall and lower enrollment can reduce the

may interact more with challenges that fall within the scope of both jobs and thus have similar views on these challenges. The library needs hardware to deliver just-intime access, and the hardware must be upgraded frequently. With the entire campus needing the same upgrading, it is reasonable to assume that the CAO is knowledgeable about hardware and the need for increases in budget to acquire it. The outcome of Richard M. Dougherty's workshops between the two groups belonging amount of resources available for budgets. Campuswide priorities, such as the installation of a fiber-optic network, can reduce funds available for the library as well.

\section{Budget}

Differences in perspectives are reflected only between training and the budget. A higher difference score related with an increased budget. This may mean that as the need for training goes up, the budget 
TABLE 4

Item Responses for Challenges given by Academic Library Directors and Chief Academic Officers from the Same Institution

\begin{tabular}{|c|c|c|c|c|c|c|c|c|c|c|}
\hline & \multicolumn{2}{|c|}{$\begin{array}{c}\text { No } \\
\text { Challenge }\end{array}$} & \multicolumn{2}{|c|}{$\begin{array}{l}\text { Minor } \\
\text { Challenge }\end{array}$} & \multicolumn{2}{|c|}{$\begin{array}{l}\text { Moderate } \\
\text { Challenge }\end{array}$} & \multicolumn{2}{|c|}{$\begin{array}{l}\text { Significant } \\
\text { Challenge }\end{array}$} & \multicolumn{2}{|c|}{$\begin{array}{l}\text { Intract. } \\
\text { Challenge }\end{array}$} \\
\hline & & $\mathrm{CAO}$ & & $\mathrm{CAO}$ & $\mathrm{LDC}$ & $\mathrm{CAO}$ & $\mathrm{LD}$ & $\mathrm{AO}$ & $\mathrm{LDC}$ & $\mathrm{CAO}$ \\
\hline $\begin{array}{l}\text { Organizational } \\
\text { Change } \\
\text { Percentage }\end{array}$ & $\begin{array}{r}5 \\
11.4\end{array}$ & $\begin{array}{r}5 \\
11.6\end{array}$ & $\begin{array}{r}13 \\
29.5\end{array}$ & $\begin{array}{r}15 \\
34.9\end{array}$ & $\begin{array}{r}17 \\
38.6\end{array}$ & $\begin{array}{r}15 \\
34.9\end{array}$ & $\begin{array}{r}9 \\
20.5\end{array}$ & $\begin{array}{r}8 \\
18.6\end{array}$ & $\begin{array}{l}0 \\
0\end{array}$ & \\
\hline $\begin{array}{l}\text { Crime } \\
\text { Percentage }\end{array}$ & $\begin{array}{r}2 \\
4.5\end{array}$ & $\begin{array}{r}2 \\
4.5\end{array}$ & $\begin{array}{r}27 \\
61.4\end{array}$ & $\begin{array}{r}20 \\
45.5\end{array}$ & $\begin{array}{r}10 \\
22.7\end{array}$ & $\begin{array}{r}19 \\
43.2\end{array}$ & $\begin{array}{r}5 \\
11.4\end{array}$ & $\begin{array}{r}3 \\
6.8\end{array}$ & $\begin{array}{l}0 \\
0\end{array}$ & $\begin{array}{l}0 \\
0\end{array}$ \\
\hline $\begin{array}{l}\text { User Satisfaction } \\
\text { Percentage }\end{array}$ & $\begin{array}{r}2 \\
4.5\end{array}$ & $\begin{array}{l}0 \\
0\end{array}$ & $\begin{array}{r}8 \\
18.2\end{array}$ & $\begin{array}{r}10 \\
22.7\end{array}$ & $\begin{array}{r}16 \\
36.4\end{array}$ & $\begin{array}{r}18 \\
40.9\end{array}$ & $\begin{array}{r}17 \\
38.6\end{array}$ & $\begin{array}{r}15 \\
34.1\end{array}$ & $\begin{array}{r}1 \\
2.3\end{array}$ & $\begin{array}{r}1 \\
2.3\end{array}$ \\
\hline $\begin{array}{l}\text { Diversity } \\
\text { Percentage }\end{array}$ & $\begin{array}{r}4 \\
9.1\end{array}$ & $\begin{array}{r}5 \\
11.4\end{array}$ & $\begin{array}{r}7 \\
15.9\end{array}$ & $\begin{array}{r}6 \\
13.6\end{array}$ & $\begin{array}{r}12 \\
27.3\end{array}$ & $\begin{array}{r}15 \\
34.1\end{array}$ & $\begin{array}{r}18 \\
40.9\end{array}$ & $\begin{array}{r}17 \\
38.6\end{array}$ & $\begin{array}{r}3 \\
6.8\end{array}$ & $\begin{array}{r}1 \\
2.3\end{array}$ \\
\hline $\begin{array}{l}\text { Hardware } \\
\text { Percentage }\end{array}$ & $\begin{array}{r}4 \\
9.1\end{array}$ & $\begin{array}{r}2 \\
4.5\end{array}$ & $\begin{array}{r}2 \\
4.5\end{array}$ & $\begin{array}{r}7 \\
15.9\end{array}$ & $\begin{array}{r}13 \\
29.5\end{array}$ & $\begin{array}{r}16 \\
36.4\end{array}$ & $\begin{array}{r}23 \\
52.3\end{array}$ & $\begin{array}{r}17 \\
38.6\end{array}$ & $\begin{array}{r}2 \\
4.5\end{array}$ & $\begin{array}{r}2 \\
4.5\end{array}$ \\
\hline $\begin{array}{l}\text { Software } \\
\text { Percentage }\end{array}$ & $\begin{array}{r}7 \\
6.8\end{array}$ & $\begin{array}{r}4 \\
9.1\end{array}$ & $\begin{array}{r}4 \\
22.7\end{array}$ & $\begin{array}{r}1 \\
2.3\end{array}$ & $\begin{array}{r}16 \\
29.5\end{array}$ & $\begin{array}{r}23 \\
52.3\end{array}$ & $\begin{array}{r}16 \\
38.6\end{array}$ & $\begin{array}{r}15 \\
34.1\end{array}$ & $\begin{array}{r}1 \\
2.3\end{array}$ & $\begin{array}{r}1 \\
2.3\end{array}$ \\
\hline $\begin{array}{l}\text { Training } \\
\text { Percentage }\end{array}$ & $\begin{array}{r}3 \\
15.9\end{array}$ & $\begin{array}{r}2 \\
4.5\end{array}$ & $\begin{array}{r}10 \\
9.1\end{array}$ & $\begin{array}{r}10 \\
22.7\end{array}$ & $\begin{array}{r}13 \\
36.4\end{array}$ & $\begin{array}{r}21 \\
47.7\end{array}$ & $\begin{array}{r}17 \\
36.4\end{array}$ & $\begin{array}{l}11 \\
25\end{array}$ & $\begin{array}{r}1 \\
2.3\end{array}$ & $\begin{array}{l}0 \\
0\end{array}$ \\
\hline $\begin{array}{l}\text { Serials } \\
\text { Percentage }\end{array}$ & $\begin{array}{l}0 \\
0\end{array}$ & $\begin{array}{l}0 \\
0\end{array}$ & $\begin{array}{r}1 \\
2.3\end{array}$ & $\begin{array}{r}1 \\
2.3\end{array}$ & $\begin{array}{r}7 \\
15.9\end{array}$ & $\begin{array}{r}1 \\
2.3\end{array}$ & $\begin{array}{r}19 \\
43.2\end{array}$ & $\begin{array}{r}25 \\
56.8\end{array}$ & $\begin{array}{r}17 \\
38.6\end{array}$ & $\begin{array}{r}17 \\
38.6\end{array}$ \\
\hline
\end{tabular}

is increased. Conversely, it may mean that when the budget goes up, the ALD uses it for training. One explanation for the need for training is automation. Another possible explanation is that automation is increasing productivity, and staff is being reassigned. It also is possible that staff are being rewarded for their hard work with training opportunities.

\section{FTE Staffing}

The greatest percentages of respondents reported "No Change" in the number of positions during the three years. The high percentage of "No Change" may indicate the possibility that technology has increased productivity as suggested by several of the researchers and that fewer employees are needed. Conversely, the large "No Change" finding could indicate a shift in responsibility. The fact that ALDs added adequate staffing as a current chal- lenge and ranked it as number two suggests that, whatever the reason for not adding staff, some libraries need additional staff to carry out the libraries' missions.

To what degree do gender, age, and length of tenure in their positions of ALDs relate to the similarity of their perceptions of the challenges? Variables such as age, gender, and length of tenure in current positions were included to determine whether they were influencing perceptions. Similarity of perceptions is seen between age and length of tenure in current position of respondents with organizational change. Similarity is seen between age and the challenge of crime in the library. In addition, similarity is seen between length of tenure and training.

\section{Organizational Change}

As age and length of tenure in current 
position increase, the directors view organizational change as less of a challenge. As age and length of tenure in current position decrease, the directors view organizational change as more of a challenge. A possible hypothesis for the different views of organizational change is that the organizations are in different life cycles. Each stage in the life cycle requires different characteristics in leaders. Another possible hypothesis is that a new person brings enthusiasm to a position and is interested in making changes. As people are in the position longer, their views may change. They may have made the changes they wanted and decided that the changes were not needed or could not be accomplished.

These differences in perspectives are important because different perspectives about the role and mission of the library could affect the existence and future of the academic library.

\section{Crime}

Similarity is seen between age and the perception of crime as a challenge. Younger directors may be reading more professional literature to get information. Because this is a topic frequently discussed, it may appear to be a great challenge. Older directors may have more library experience and thus have installed crime prevention measures.

\section{Training}

As length of tenure shortens for respondents from the overall group, the intensity of challenge for training increases. As length of tenure increases, the intensity of the challenge for training decreases. For respondents from the same institution, the relationships are nearly tenable as well. A possible explanation is that a natural enthusiasm in a new position may bring with it a belief in training. Someone who has been in his or her position longer may have decided from past experience that training will not make a difference with some employees.

Age and length of tenure in position seem to be operating to influence the per- ceptions about challenges held by the ALDs. Gender was not related to the similarity of their perspectives.

To what degree do gender, age, and length of tenure in their positions of CAOs relate to the similarity of their perceptions of the challenges? The study found no relationship with age or length of tenure and perceptions of challenges held by the CAOs. A relationship between gender and perceptions of serials as a challenge was found. According to the test conducted, the selection of a higher intensity of challenge would be predicted for females belonging to the overall group. This finding may be an anomaly because only ten out of fifty-nine of the CAOs were female. Further research is needed to substantiate the finding.

\section{Additional Challenges}

Both academic library directors and chief academic officers added job-related challenges to the survey-provided list. Some of the added challenges were ranked, and others were added but not ranked. It is assumed that these are challenges of equal rank to many of the survey-provided challenges. The additional challenges provide added insight about perceptions of the academic library directors' challenges. Academic library directors added fortyeight additional job-related challenges whereas the chief academic officers added twenty-four. Up to three challenges could be added by each respondent, and some did not add any. Tables 5 and 6 provide the data.

Job-related challenges that seemed to be more apparent to the two groups are categorized by the researcher into four ad hoc topics: "staffing issues," "technology," "the library's role," and "miscellaneous" ("misc"). This last category provides for a somewhat eclectic assortment of challenges given by each group. Some of the challenges could fit into several of the topics.

Staff was the most frequently added topic by ALDs (22.9\%). The library's role was the most frequently added topic by CAOs (16.7\%). One explanation is that the 
directors work closely with staffing problems and are most familiar with library staffing needs. CAOs, on the other hand, may consider staffing an issue that is handled by each department head while the $\mathrm{CAO}$ concentrates on achieving the campus's overall mission. These differences in perspectives are important because different perspectives about the role and mission of the library could affect the existence and future of the academic library. A problem with integrating the li-

TABLE 5

Challenges at Any Ranking Added by Academic Library Directors

\begin{tabular}{|c|c|}
\hline Challenge & Frequency \\
\hline Staffing Issues & 18 \\
\hline Hiring an adequate number of staff; funding for staff & 11 \\
\hline Staff morale/motivating staff with little chance of reward & 3 \\
\hline Hiring and retaining professional librarians & 3 \\
\hline Lack of turnover in staff & 1 \\
\hline Technology & 15 \\
\hline Keeping up with the changes in technology & 3 \\
\hline Distance education & 3 \\
\hline $\begin{array}{l}\text { Information technology being valued more than information by } \\
\text { faculty and administration }\end{array}$ & 1 \\
\hline Conveying technical information to administration & 1 \\
\hline Bibliographic instruction for multiformats & 1 \\
\hline Technology training & 1 \\
\hline Impact of e-mail on staff, including the director & 1 \\
\hline Orienting administration to "just-in-time" access & 1 \\
\hline Acquiring electronic support staff & 1 \\
\hline Costs of new electronic databases & 1 \\
\hline Librarian attitudes toward/lack of background in computer use & 1 \\
\hline Miscellaneous & 9 \\
\hline Funding for books and other materials & 2 \\
\hline Acquiring additional funds from the general budget & 1 \\
\hline Fund-raising & 1 \\
\hline Demands of boards and accrediting agencies & 1 \\
\hline Dealing with internal bureaucracy & 1 \\
\hline Creating a learning organization & 1 \\
\hline Outcomes assessment & 1 \\
\hline Aging building with inadequate wiring & 1 \\
\hline Library's role & 6 \\
\hline Promoting library's role in information literacy; information & \\
\hline $\begin{array}{l}\text { literacy for students } \\
\text { Orienting faculty to the changing role of librarianship }\end{array}$ & $\begin{array}{l}2 \\
1\end{array}$ \\
\hline Overall collection development in disciplines & 1 \\
\hline Direction of library in the future & 1 \\
\hline $\begin{array}{l}\text { Organizational change within the university that places library } \\
\text { under the same category of "information technology" away from } \\
\text { the academic component of the university }\end{array}$ & 1 \\
\hline TOTAL & 48 \\
\hline $\mathrm{n}=59$ & \\
\hline
\end{tabular}


TABLE 6

Challenges at Any Ranking Added by Chief Academic Officers

\begin{tabular}{lc}
\hline \hline \multicolumn{1}{c}{ Challenge } & Frequency \\
\hline Library's Role & $\mathbf{1 1}$ \\
\hline Collection Development- & 4 \\
To meet program needs and new program needs & $(2)$ \\
Upgrading collections/services for Ph.D.-level programs & $(1)$ \\
Determining collection dev. policies in view of impact of technology & $(1)$ \\
Meeting faculty and student needs & 2 \\
Expansion into other media (video, CDs) & 1 \\
Providing support for new programs & 1 \\
Integrating the library with the mission of the university & 1 \\
Organizational fit with new technology & 1 \\
Library services for a multicampus university & 1 \\
Miscellaneous & $\mathbf{7}$ \\
\hline New facility/additions to facility & 3 \\
Develop a plan for resource allocations & 1 \\
Acquiring funding for updating holdings & 1 \\
Rising book costs & 1 \\
Rising costs & 1 \\
Staffing Issues & $\mathbf{4}$ \\
\hline Salaries & 2 \\
Achieving worker satisfaction & 1 \\
Keeping library staff open to change & 1 \\
Technology & $\mathbf{2}$ \\
\hline Virtual library & 1 \\
Provide support for distance education & 1 \\
\hline TOTAL & $\mathbf{2 4}$ \\
n 59 & \\
\hline
\end{tabular}

brary in the university's mission was mentioned by some respondents from both groups. More research is needed to determine whether differences in perspectives about the library's role and mission are held by these two key groups.

It is interesting that the added challenges from both groups could be placed within the same categories. Particularly illuminating are the frequencies given for the library's role and for technology. Chief academic officers added more challenges in the category of "the library's role" whereas the academic library directors added more challenges in the category of "technology." Academic library directors added fewer challenges that could be placed in this category. This could indi- cate that some confusion exists in some institutions about the library's role in the technological age and, by extension, the library director's role.

\section{Ranked Challenges}

Both groups ranked user satisfaction and serials in the top three categories. Both of these challenges are important issues. Users are more sophisticated and expect more from both the library and the university. Serials have presented challenges because of the huge increase in cost for libraries and users campuswide.

Diversity was ranked either number two or number three by CAOs. Diversity seems to be a high priority with these administrators. Their positions would 
allow them a campuswide view of the student population and employee needs.

ALDs ranked adequate staffing as number one. This is a respondent-added challenge. The addition and ranking of it as number one by the directors suggests that the two groups' perceptions of the most important challenges differ. These two important challenges are integrally connected, however. It may be difficult to give good customer service that results in user satisfaction without adequate staff to provide the service. (See table 7.)

An interesting observation is that 45.7 percent of CAOs ranked user satisfaction as number one, but only 39.0 selected the intensity of "significant" or "intractable" to describe in the first section of the questionnaire. Perhaps when some answered this, they had begun to think of it in terms of the entire campus.

Table 8 provides the complete list of ranked challenges, including the ones added by respondents. Analysis of the list shows that the eight challenges were ranked in the top three categories. This indicates that important challenges are being discussed in the literature. Analysis shows that crime was given a number two or three ranking by nine chief academic officers. Considering their ratings of crime on the eight questions, this is interesting. An explanation is that some respondents switched to campus issues when they ranked the challenges. Analysis also shows that other challenges are present, at least for the respondents adding challenges, this may not be a frequent topic of articles.

\section{Conclusion}

The following conclusions were drawn from the results of the study and the procedures used. Limitations that may have been present in the study which may have influenced the findings include limited range of options for the respondents to rate the intensity of each challenge, no measure to check the accuracy of the participants' responses, no measure to determine bias to make respondent "look good," and use of only two variables to indicate organizational outcomes. The respondents from the same institution may have different perceptions from those of the overall group of respondents. Some differences, though not significant, were found. Considering limitations, the following conclusions are drawn.

\begin{tabular}{|c|c|c|c|c|c|}
\hline \multicolumn{6}{|c|}{$\begin{array}{c}\text { TABLE } 7 \\
\begin{array}{c}\text { Frequency of Challenges That Were Ranked Number One, Number Two, } \\
\text { and Number Three by the Two Groups }\end{array} \\
\end{array}$} \\
\hline \multicolumn{3}{|c|}{ Academic Library Directors } & \multicolumn{3}{|c|}{ Chief Academic Officers } \\
\hline Challenge & Freq. & Percent & Challenge & Freq. & Percent \\
\hline \multicolumn{6}{|c|}{ Number One Rankings } \\
\hline Serials & 22 & 37.0 & Serials & 27 & 45.7 \\
\hline Adequate Staff & 7 & 14.5 & User Satisfaction & 11 & 18.6 \\
\hline \multicolumn{6}{|c|}{ Number Two Rankings } \\
\hline Serials & 13 & 22.0 & Diversity & 13 & 22.0 \\
\hline User Satisfaction & 9 & 15.3 & Serials & 11 & 18.6 \\
\hline \multicolumn{6}{|c|}{ Number Three Rankings } \\
\hline User Satisfaction & 11 & 18.6 & Diversity & 15 & 25.4 \\
\hline Serials & 9 & 15.3 & User Satisfaction & 12 & 20.3 \\
\hline
\end{tabular}




\begin{tabular}{|c|c|c|c|c|c|c|}
\hline \multicolumn{7}{|c|}{$\begin{array}{c}\text { TABLE } 8 \\
\begin{array}{c}\text { Frequencies for Number One, Number Two, and } \\
\text { Number Three Rankings-All }\end{array} \\
\end{array}$} \\
\hline & \multicolumn{2}{|c|}{$\begin{array}{c}\text { Number } \\
1\end{array}$} & \multicolumn{2}{|c|}{$\begin{array}{c}\text { Number } \\
2 \\
\end{array}$} & \multicolumn{2}{|c|}{$\begin{array}{c}\text { Number } \\
3\end{array}$} \\
\hline & ALD & $\mathrm{CAO}$ & ALD & $\mathrm{CAO}$ & ALD & $\mathrm{CAO}$ \\
\hline Organizational Change & 3 & 4 & 4 & 7 & 4 & 6 \\
\hline Crime & 1 & 0 & 1 & 3 & 1 & 6 \\
\hline User Satisfaction & 6 & 11 & 9 & 8 & 11 & 12 \\
\hline Diversity & 5 & 10 & 7 & 13 & 5 & 15 \\
\hline Hardware & 2 & 3 & 4 & 6 & 7 & 4 \\
\hline Software & 2 & 2 & 5 & 4 & 5 & 6 \\
\hline Training & 1 & 2 & 5 & 7 & 3 & 7 \\
\hline Serials & 22 & 27 & 13 & 11 & 9 & 6 \\
\hline Adequate Staff & 7 & 2 & 2 & 0 & 2 & 0 \\
\hline Virtual Library & 1 & 1 & 0 & 1 & 0 & 0 \\
\hline Staff Morale & 2 & 2 & 1 & 2 & 1 & 0 \\
\hline Tech. Change & 3 & 0 & 0 & 0 & 1 & 0 \\
\hline Distance Education & 2 & 0 & 0 & 1 & 0 & 0 \\
\hline Collection Develop. & 0 & 1 & 1 & 1 & 0 & 3 \\
\hline Facilities/space & 1 & 2 & 1 & 0 & 0 & 3 \\
\hline Library Relevancy & 0 & 0 & 2 & 0 & 0 & 0 \\
\hline Promoting the Role & 2 & 0 & 1 & 0 & 2 & 0 \\
\hline Campus Needs & 0 & 1 & 0 & 2 & 0 & 1 \\
\hline Library Fit with University & 0 & 0 & 1 & 2 & 1 & 0 \\
\hline Funding/books & 0 & 2 & 0 & 0 & 1 & 0 \\
\hline Hiring Professional Librarians & ns 0 & 0 & 0 & 0 & 2 & 1 \\
\hline Others & 4 & 4 & 5 & 1 & 3 & 1 \\
\hline Totals & 64 & 74 & 62 & 69 & 58 & 71 \\
\hline
\end{tabular}

The study found evidence that age and length of time in position of ALDs are related to perceptions about organizational change and crime in the library as challenges. These variables may be responsible for some difference in perceptions about these challenges. A potential hypothesis is that ALDs coming to the position recently hold stronger perceptions that there is a need for change. Conversely, the longer one is in a position, the less intense may be one's perceptions. In the latter case, a person may have made the changes he or she wanted and decided that they were unnecessary or not changeable.

The directors in the study's sample are staying longer in their positions (10.54 years) than were the directors in the 1993
McAnally and Downs study (approximately six years), in the Euster study (7.5 years), and in the Mech study (8.4 years). ${ }^{23}$ Because the present population has rarely been studied, no statistics exist with which to compare directors from these institutions. It is possible that regionalism may be a factor that contributes to the longer tenure for the study's group. Additional research can determine whether tenure rates are changing and are influenced by region.

The gender ratio of the study's sample of ALDs is higher than Euster or Mech found for their samples. Euster (1989) found that 23.8 percent of the ARL directors were female; Mech (1990) found that 30.6 percent of liberal arts college directors were female. ${ }^{24}$ The present study 
found that 39 percent of the directors were female. Because no earlier data have been found for library directors from the study's institutions, no conclusion can be drawn about changes within the population.

The researcher concludes that for this group, training and budget are related. As differences in intensity for the challenge of training increased, so did budgets. Staffing numbers generally did not change. This suggests that the directors may be requesting more funding for training or may be using any budget increases for training. The need for training reflects the situation of the organization. Staff reassignment is indicated when considering that staffing numbers generally did not increase. The training also may be needed for updating technological skills. This would tend to reinforce the views of the participants in the Riggs and Sabine study and of others. ${ }^{25}$

The study's findings indicate that the challenges listed most frequently in the professional literature represent many of the challenges that the study ALDs are experiencing with the exception of the challenge of crime in the library. However, the respondent-added challenges indicate that other challenges are more apparent to some of the respondents. Moreover, the difference in perspectives between the two groups indicates some dissonance. One explanation for the differences in challenges from the literature is that some challenges may be more popular as topics in publications. Another explanation is that the respondent-provided items were not challenges before but have increased in intensity for some of the respondents or that the challenges may be local. Another hypothesis is that some are new challenges. The ranking of some respondent-provided challenges as number one indicates that, at least for some directors and their supervisors, the frequency of appearance in articles only limitedly reflects their challenges.

Because the study found that both groups of administrators ranked user satisfaction in the top three rankings of im- portance, it is a high priority with them. Approximately 35 percent of both groups rated their intensity of challenge to user satisfaction as "significant," indicating that it is not an easily solved challenge. Schools of library and/or information studies may consider including more courses in customer relations/customer services.

\section{Future Research Needed}

One of the goals of the present study was to provide a broad overview of perceptions to challenges held by the two groups. Future research using a qualitative study could provide an in-depth view of perceptions of challenges. The sample size for the present study was large enough to provide information for the research; however, increasing the sample size should provide greater opportunity for new challenges to be detected. The study's respondents for the most part answered using all five levels of intensity that indicated degree of challenge. Another study providing additional options for levels of intensity would make a survey instrument more sensitive in identifying differences in perspectives.

The study provides some evidence that the difference in perceptions about training is related to increased budgets. Its findings also indicate that older ALDs and the ones who have been in the position longer viewed training as a less intense challenge. On the other hand, the indication is that younger directors who have been in their positions for a shorter period of time viewed training as a greater challenge. The relationship may indicate the natural enthusiasm one has in a relatively new position and the belief that training will bring change. The longer-tenured directors may have supported training in the past and/or now have a trained staff and/or no longer believe training will make a difference with some employees. Training may be an indication that staff is being reassigned, that skills for using new technology are being updated, and/or that it may be a reward for hard work. Training is needed when 
basic and fundamental change is occurring. The need for training reflects the situation of an organization facing change as well. Intervening variables are possible here. Additional research is needed to determine the relationship of incumbency, training, and change.

Because the study was limited to public institutions in the South, it should be replicated using different populations to determine whether perceptions and differences in perspectives about the challenges are similar. Future studies should determine whether the challenge of training may be related to budget in other public and private organizations.

Respondent-added challenges indicate that other challenges are more apparent to some of the respondents. It is possible that some challenges are more popular as topics in publications. Another explanation is that the respondent-provided items were not challenges before but have increased in intensity for some of the respondents or that the challenges may be local. Another possible hypothesis is that some are new challenges. The ranking by some of the respondents of some respondent-provided challenges as number one indicates that, at least for some directors and their supervisors, the frequency of appearance in articles only limitedly reflects their challenges.

The categories of staffing, the library's role, and technology offer areas for future research. Library directors added and ranked staffing challenges as number one over the survey-provided challenges. Although the literature discusses staffing, this topic did not appear in the eight most frequently discussed list of challenges as this researcher analyzed the topics. Challenges about the library's role was added by both groups, but the CAOs added more challenges in this category and the ALDs added fewest. The library's role was not among the eight the most frequently published topics as the researcher identified them. The technology category also offers insight. Although the directors added fifteen challenges in this category, their supervisors added only two. Some directors may not be viewing the library in terms of technology. More research is needed to determine the extent of these challenges.

Future research is needed to determine where administrators (ALDs and CAOs) get information about challenges in the field. Sources for information may include professional literature, colleagues in the field, e-mail, and/or listservs. Future research should determine the types of listservs used and why as well as how much the Internet is used to gather information in smaller public institutions compared with private and public institutions.

The study's findings indicate that diversity is an important challenge for the CAOs in the public universities. Several experts consulted for the challenge list emphasized that diversity is a societal problem not easily solved. Support mechanisms may be necessary for the success of a diverse workforce as well. Future research is necessary to determine diversity as it exists in academic library settings, universities, and other organizations, as well as support mechanisms used to help ensure success in a diverse workplace.

The study found that, in general, budgets did not appear to increase much over the three years. It also found that the two groups' perceptions about hardware were similar, although no significant relationship was established between hardware and budget. Although institutions have provided for the initial outlay of funds for these tools in libraries, obsolescence makes hardware and software useful only to the degree that they meet current user needs. Future research is needed to determine the availability of resources in academic libraries and universities to upgrade hardware and software as technological obsolescence continues.

The study provides some evidence that gender influences perspectives. The study found that only ten CAOs were female. In addition, only three female ALDs reported to female CAOs. Other studies could provide enlightenment about this study's finding. Factors such as experience, com- 
munication style, or a common language based on gender may exert influence on the perceptions of males or females.

There was some evidence that CAOs who answered the survey with the ALD hold somewhat different perceptions from those who did not respond. More research could provide enlightenment about these key administrator's views about the library. Robert F. Munn (1968) and William A. Moffett (1981) found that top administrators did not think much about the library except maybe to think of it as a "bottomless pit." ${ }^{26}$ Hardesty, in 1991, found evidence that these administrators do think of the library and support it. ${ }^{27}$ The present research supports Hardesty's findings. In 1959, C. P. Snow proposed a theory of "two cultures" to describe the existence of cultures that seem to be competing in organizations: a traditional culture and a scientific culture. ${ }^{28}$ More study concerning CAOs could determine whether "two cultures" (to borrow his phrase) exist here.

\section{Concluding Summary}

It is important to continue this research for several broad reasons. First, during times of rapid change, new challenges along with current challenges appear in organizations that may lead, ultimately, to leadership turnover. If the same challenges exist for the new leader, they too may become discouraged and leave. It is important that the leader's supervisor understand challenges that the leader experiences so that the organization is not negatively affected. If a leader or his or her supervisor is experiencing different perceptions of the challenges, they may act on their beliefs to the detriment of the organization.

The present study focused on ALDs and the CAOs to whom they report; however, the manager-supervisor relationship exists in other organizations both public and private. Much is known about the challenges of library directors who belong to the ARL. Little is known, however, about the library directors in public institutions. This research and future research on the topic can fill that gap.

New challenges often require new conceptualization efforts and skills to resolve. Studies are needed to provide a fresh look at challenges in organizations in times of rapid change. It is important that future leaders gain an essential educational background so that appropriate solutions can be identified and applied to challenges.

\section{Notes}

1. Charles G. Newman, "Selection, Career Paths, and Managerial Development in Academic Library Administration: Forecasting the Needs of the Twenty-first Century," in Academic Libraries: Their Rationale and Role in Higher Education, ed. Gerald B. McCabe and Ruth J. Person (Westport, Conn.: Greenwood Pr., 1995).

2. Joanne R. Euster, The Academic Library Director: Management Activities and Effectiveness (New York: Greenwood Pr., 1987).

3. Ibid., 45. 219-29.

4. Larry Hardesty, "The Bottomless Pit Revisited," College E Research Libraries 52, no. 3 (1991):

5. Arthur M. McAnally and Robert B. Downs, "The Changing Role of Directors of University Libraries," College E Research Libraries 34 (Mar. 1973): 103-25.

6. In 1994, Rooks updated the McAnally and Downs research. She found that the pressures were "largely unchanged." In 1991, Myers and Kaufman surveyed to determine the relationship between university directors and factors of age, gender, length of service, and so on. See these studies: Marcia J. Myers and Paula T. Kaufman, "ARL Directors: Two Decades of Change," College E Research Libraries 52 (May, 1991): 241-54; Dana C. Rooks, "Terms for Academic Library Directors," Library Trends 43 (summer 1994): 60, 61; Keith M. Cottam, "Directors of Large Libraries: Roles, Functions, and Activities," Library Trends 43 (summer 1994): 15.

7. George A. Stalliard Sr., "A Study of the Relationship between Leadership Behavior and Voluntary Turnover in a Public Sector Organization" (Ph.D. diss., Nova Southeastern Univ., 1997); Stephen Worchel, Stephen M. Jenner, and Michelle R. Hebl, "Changing the Guard: How Origin 
of New Leader and Disposition of Ex-leader Affect Group Performance and Perceptions," Small Group Research 29 (1998): 436-51.

8. McAnally and Downs, "The Changing Role of Directors of University Libraries."

9. Myers and Kaufman, "ARL Directors"; Rooks, "Terms for Academic Library Directors"; Cottam, "Directors of Large Libraries."

10. Ruth H. Person and Sharon J. Rogers, Recruiting the Academic Library Director (Washington, D.C.: Association of College \& Research Libraries, 1988).

11. Ibid,. 1.

12. Barbara Brittingham, "The Library, Information, and Institutional Outcomes: Searching in a Time of Change," Journal of Library Administration 24, no. 3 (1997): 59-71.

13. Paul J. Kobulnicky, "Between the Acts: The Interim or Acting Director of a

Research Library," Journal of Library Administration 24, no. 3 (1997): 3-29.

14. Donald E. Riggs and Gordon A. Sabine, Libraries in the '90's: What the Leaders Expect (Phoenix, Ariz.: Oryx Pr., 1988).

15. Susan Jurow, "Preparing Academic and Research Library Staff for the 1990's and Beyond," Journal of Library Administration 17, no. 1 (1992): 5-17.

16. Kobulnicky, "Between the Acts."

17. Brittingham, "The Library, Information, and Institutional Outcomes."

18. See Lloyd W. Chapin and Larry Hardesty, "Benign Neglect of the Heart of the College: Liberal Arts College Deans Look at the Library," in Academic Libraries: Their Rationale and Role in American Higher Education," ed. Gerald B. McCabe and Ruth J. Person (Westport, Conn.: Greenwood Pr., 1995); Richard M. Dougherty and Carol Hughes, Preferred Futures for Libraries: A Summary of Six Workshops with University Provosts and Library Directors (Mountain View, Ark.: Research Libraries Group, 1991).

19. Ibid.; Chapin and Hardesty, "Benign Neglect of the Heart of the College," 29-41; Robert Munn, "The Bottomless Pit, or the Academic Library from the Administration Building," College $\mathcal{E}$ Research Libraries 26, no.1 (1968): 51-54; William A. Moffett, "Don't Shelve Your College Librarian," Educational Record 63, no. 3 (1982): 46-50.

20. See Susan Lee, "The Role of the Academic Library Director: An Exploratory Investigation" (Ph.D. diss., Simmons College, 1976); Alma Dawson, "The Academic Library in Intra-Institutional Relationships: Case Studies in Library Finance" (Ph.D. diss., The Texas Woman's Univ., 1996); Chapin and Hardesty, "Benign Neglect of the Heart of the College," $29-41$.

21. Thomas W. Shaughnessy, "The Library Director as Change Agent," in Managing Change in Academic Libraries, ed. Joseph J. Branin (New York: Haworth Pr., 1996).

22. Dougherty and Hughes, "Preferred Futures for Libraries."

23. McAnally and Downs, "The Changing Role of Directors of University Libraries."

24. Euster, "The Academic Library Director"; Terrance F. Mech, "Academic Library Directors: A Managerial Role Profile." College E Research Libraries 51, no. 4 (1990):415-428.

25. Riggs and Sabine, "Libraries in the '90's"; Charles Brad Robison, "Effects of Automation on Academic Libraries" (Ph.D. diss., Oklahoma State Univ., 1991).

26. Munn, "The Bottomless Pit, or the Academic Library from the Administration Building"; Moffett, "Don't Shelve Your College Librarian."

27. Hardesty, "The Bottomless Pit Revisited."

28. C. P. Snow, The Two Cultures: and a Second Look. An Expanded Version of the Two Cultures and the Scientific Revolution by C.P. Snow. $2^{\text {nd }}$ ed. (Cambridge, Mass.: University Pr., 1964). 